\title{
Impact of Microfinance Services on the Empowerment of Women and Youth: Evidence from Rural Farmers in Anambra State, Nigeria
}

\author{
Longinus Chukwuma Ejiogu, Renato Andrin Villano
}

\begin{abstract}
Often times, microfinance services have been ascribed the role of creating employment opportunities, income generation, as well as poverty reduction, among beneficiaryresource poor rural households across developing countries. This study examined the impact of microfinance services on empowered rural farmers in Anambra State of Nigeria, especially the financial sustainability of women and youth. The 80 respondents selected and interviewed were those that benefited from the microfinance services. The data collected were presented and analyzed using descriptive statistics and content analysis. The results revealed that microfinance services contributed to employment generation, improvedincome as well as the standard of living and general wellbeing of the respondents. This study can also be further extrapolated by incorporating more factors as well as increasing the sample size in order to get more significant results from a wider area.
\end{abstract}

Index Terms - Empowerment, Microfinance, Rural Farmers, Women and Youth.

\section{INTRODUCTION}

Highlight The concept of microfinance is not new, especially in Nigeria where it has always been a tradition of the people, asystem of savings and taking loans by individuals or groups within the context of self-help to support their micro enterprises or farming activities especially by rural dwellers.Esusu, as is popularly known in Nigeria,is one of the oldest microfinanceprogrammesin the country which has now spread to other West African countries. Microfinance, as is known today, was introduced in Nigeria in 2005 after a recommendationby the World Bank (Awojobi, 2014). There is no doubt that microfinance activities have been an important vehicle of development strategy globally, especially in developing countries. It is a means of local development in most developing nations (Berglund, 2007). Microfinance services refer mainly to small loans, savings mobilization and training in micro enterprise investment services extended to poor people, particularly women, to enable them undertake self-employment projects that generate income (Ondoro and Omena, 2012). It is an economic development strategy that focuses on rebuilding and restarting local economics by providing needed financial services for enterprise creation (Reyes and Fattori, 2019). According to Al-Hassan (2011),

Longinus Chukwuma Ejiogu, Principal Agricultural Officer, Federal Ministry of Agriculture and Rural Development, Abuja Nigeria

Renato Andrin Villano, Professor of Economics and specializes in the area of Applied Econometrics, Agricultural Economics and Development Economics, University of New England, Armidale, Australia microfinance is the provision of financial services, either credit or savings, to a number of micro, small and medium entrepreneurs, the productive and resource poor, especially women and youth in a cost effective and sustainable manner. In another view, Omunjalu and Fondo, 2014, asserted that microfinance is the practice of providing financial services such as micro credit, micro saving or micro insurance to poor or disadvantage individual by helping them to accumulate large sums of money thereby expanding their choice and reduce risk. Appiah (2011) also stated that microfinance is the provision of financial services to low income people or solidarity lending groups including consumers and self-employed who traditionally lack access to banking and related services.Over time, it has been an innovative and sustainable approach in the empowerment of women and youth in the generation of income in order to improve their livelihood and contribute to economic growth. Women and youth constitute more than half of the population of any country yet their unemployment rate is higher than that of men. Therefore, women and youth participation in economic programmes is very necessary for economic growth and nation building (Rahman et.al. 2017). The link between microfinance servicesto development was clearly established in 1976 when Professor Yunus Muhammad set up a micro-loan initiative for poor villagers using his money (Rahman et.al 2017, Ondoroand Omana 2012). The purpose was to provide collateral free loans to the poor in Bangladesh, especially in rural areas, and the programme became popular asGrameen Bank. The bank has since been a source of inspiration for similar micro credit institutions in many countries and as a result, its operational model had been replicated the world over. According to Mecha (2017) the conventional banking practices had in-built constraints that were aimed only at those who were already well off. $\mathrm{He}$ argued that if financial resources were made available to the poor at reasonable terms and conditions, the poor could generate productive employment without external help. Thus, microfinance is seen purely as a tool for the poor and provides banking services to the poor, including women and youth. In Nigeria for example, access to credit has been recognized as a critical tool for promoting SMEs and poverty reduction (Njoora and Kyalo 2014). Empowering women is, by extension, viewed as a vital tool for alleviating poverty. Sujatha and Malyadri (2015), asserted that empowering women and youth contribute to the health and productivity of the entire family and communities and also improves the prospects of the next generation. Women and youth 
empowerment has since become a global challenge because majority of women and youth have been relegated to the background having been subjected to the control of men due to unfair social, cultural and political structures in many parts of the world (Nguyen 2018).

Generally, micro credit programmes in Nigeria are implemented by Financial NGOs, Financial Cooperatives, Micro Financial Institutions, Commercial banks and specialized programmes implemented bygovernment Ministries, Departments and Agencies (MDAs).These institutions have the potential to accelerate socio-economic development of the country. It is a known fact that access to credit or finance is a key factor in empowering women and youth. However, women and youth in Nigeria generally lack access to financial services from banks or other financial institutions for lack of collateral security.

Consequently, the Nigeria government has continued to support various initiatives that are focused on reducing gender inequalities and promoting women and youth empowerment in economic, social, education, training and employment. In spite of these, however, much still needs to be done in this regard because microcredit programmes evolve as a reaction strategy to the failure of making development intervention strategies include women and youth in their planning and implementation (Selome and Tshuma, 2014). Across Sub Saharan Africa microcredit operations are also conducted through microfinance institutions, similar to commercial banks, except that lending and borrowing is done with the aim of helping the poor to access credit who may not be in a position to access credit from the conventional banks as result of lack of collateral (Mondal, 2011).

\section{STATEMENT OF THE RESEARCH PROBLEM}

There has been a debate in recent years on whether microfinance really provides empowerment opportunitiesas touted for women and youth who make up the majority of the poor in most developing countries, especially their access to financial services.Microfinance programmesusually seek to enable women and youth to take a greater role in household decision making, greater access to financial and economic resources, greater social network and more bargaining power (Mayoux 2002).

This study focuses on determining the impact of microfinance services on empowerment, financial sustainability and outreach contribution to women and youth in the study area. Microfinance plays an important role in alleviating poverty, especially where the under privileged have limited access to financial services. Thus, the major objective of microfinance programmes is to provide opportunity for the poor to access financial services in order to be involved in income generating activities, thereby leading to economic empowerment of the mostly poor women and youth. However, Asim (2009) argues that participation in microfinance activities do not always ensure empowerment but may only help in partial empowerment. Microfinance itself faces challenges of self-sustainability as well as limited outreach. For one, there have been several criticisms from micro entrepreneurs about insufficient credit facilities from microfinance. Also, the assumption that microfinance services reduces poverty and empowers women and youth remains contentious. Thus, in order to address the aim of this study, the following research questions are deemed pertinent.

(1) What level of control do women and youth have over their loans?

(2) What impact do financial services have on women and youth entrepreneurs?

\section{RESEARCH OBJECTIVES}

The overall objective is to determine the impact of microfinance services to the rural women and youth farmers in Anambra state, Nigeria, whilst the specific objectives of the study are:

i. To determine the socio-demographic variables of the respondents.

ii. To determine the challenges facing women and youth smallholder farmers in accessing financial services.

iii. To ascertain the impact of microfinance financial services on the empowerment of women and youth in the study area.

iv. To determine the impact of microfinance services on poverty reduction, savings, income enhancement, health and education of the target group.

\section{CONCEPTUAL FRAMEWORK}

In general terms, microfinance is regarded as the banking institution of the poor by which they access loans, without collateral, to start up small businesses or engage in farming activities. Sometimes the loans are paid back either on weekly or monthly installments. Operationally,microfinance institutions usually prefer to give loans to groups rather than individuals as a means of providing security for the loans (Rahman and Khanam, 2017). Microfinance services that foster group formation and self-management by women have additional potential to empower women through exposure to new ideas, mutual support, fostering and identity beyond the family and the opportunity to cultivate leadership roles and responsibilities (Addai, 2017). Group lending, therefore, is one of the most important approaches employed by microfinance institutions to provide small and micro loans to disadvantaged people who lack access to credit and do not have collaterals to guarantee the loans (Alshebami and Khandare, 2015).

The conceptual framework portrays an effect relationship between microfinance services and financial empowerment of women and youth through changes in their income, savings, investment, financial management and their general well-being. 


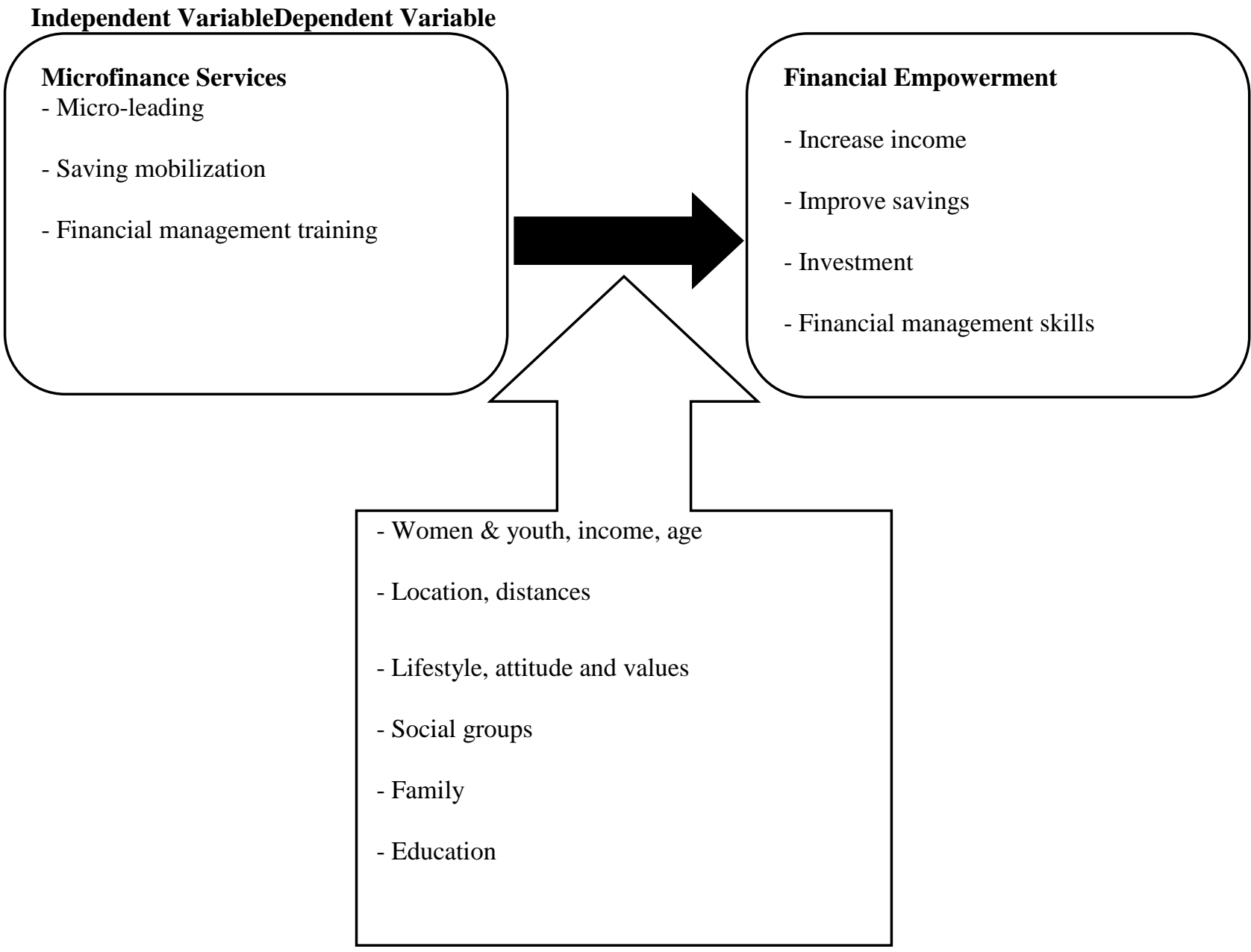

Fig. 1: Conceptual Framework

This framework consists of the dependent and independent variables. For this study, the financial empowerment of women and youth is the dependent variable and which also depends on microfinance services.

\section{LITERATURE REVIEW}

Economic growth or development through poverty reduction is the main concern of the developing world (Akhter and Islam 2016). When economic development occurs, women and youth will participate more in decision making process and the women can take good care of their children's wellbeing (Datta and Sahu 2017). Microfinance is well known as a strategy for reducing poverty among large and diverse groups of people (Alhassan, 2011). The microcredit, in the form of small loans to women or youth, are always considered a tool for empowering women towards change in their socio-economic conditions.According to Sinha (1998), credit programmes empower women and youth by strengthening their socio-economic roles, increasing their ability to contribute to their family income as well as assisting them to establish their identity outside the family and giving them experience and confidence in the public. In Nigeria, for example, most of the microcredit programmes target women and youths. This is because women and youth are more vulnerable and as such there is need to empower them through the provision of credit. Women and youth generally used the credit to expand their small businesses and enhance their status in the communities. Women and youth empowerment is considered as the process of improving the welfare of women and youth which is indicated by the outcomes that measure present status regarding Education, Health, Nutrition, Employment, Ownership of assets etc (Rahman and Khanam 2017). Usually women and youth empowerment consists of the capability to have choices as well as bargaining power. Kabeer (2017) defines empowerment as the expansion in the capacity to make strategic and meaningful choices by those who have previously been denied the capacity in ways that do not reproduce and may actively challenge the structures of inequality in the society. The process of transiting from being un-empowered to becoming empowered is known as empowerment (Reyes and Fattori 2019). Furthermore, the term empowerment is complex with lot of facets. Many researchers have defined empowerment in various ways such as the process of awareness, capacity building, greater participation, decision making, control and transformative action (Datta and Sahu 2017). Nagaraja (2013), describes it as a process by which those who have been denied the ability to make strategic life choices acquire such ability. According to Daza (2017), women and youth empowerment is a multidimensional process that also implies the self-evolution of women in more meaningful transformation in the society. The setting up of microfinance has been identified as a means of diversifying income earning opportunities, building 
financial and other assets and improving the socio-economic condition of poor, while strengthening crisis-coping mechanism (Herath et.al 2016). According to Doyle (1998), microfinance is an economic development strategy that focuses on rebuilding and restarting local economies by providing needed financial services for enterprise creation. This corroborates thegeneral assumption that providing access to microcredit and other financial services to women and youth will eventually lead to economic empowerment and general social wellbeing for the entire household in the society (Mayoux 2002).Microfinance is all about financial services provided in small loans to the poor to start or expand micro enterprises that will improve their living condition by improving earning capacity and empowerment. (Shakya, 2016). According to Reed (2011) cited by Mukhooli (2015), 104.7 million women accessed microcredit services out of 128.2 million people. The number of the poorest women with access to microcredit services increased from 10.3 million in 1999 to 104.4 in 2009 especially in developing countries.

However, women and youth empowerment goes beyond access to economic resources. Reyes and Fattori (2019) stated that the assumption that microfinance can empower women and youth sound promising but the real scope of microfinance as a means for empowerment both in peaceful and conflict settings must be accurately revised. Whilst microfinance cannot empower women and youth directly, it can help them through training and awareness to challenge the existing norms, cultures and values which place them at a disadvantage in relation to men (Addai, 2017). Thus, in order to empower women and youth, financial awareness and education should be prioritized since majority of women and youth are less financially literate than men (Hung, et.al 2012). They stated thatthe lack of financialliteracy oftentimes discourages them from actively participating in the economy. That is why microfinance plays an important role in financial inclusion and reaching out to areas were conventional banks could not provide access. Microfinance is regarded as a powerful tool to fight against poverty and under development and its fundamental principles is to provide financial services to the poor populace at the time of their need and at their own place and convenient condition (Kabees, 2005 cited by Kafle, 2015). According to Mayoux (2009), women in developing countries especially in rural areas lack access to banks and other financial institutions. Although men and women are poor, women and youth are poorer than men due to the patriarchal social structure. However, microfinance more often targets women because they have proven to be good savers, cooperative better, repayment and willing to work in group (Mayoux 2002). Other studies have also shown that women sometimes have little or no control over their loans, with the husband or male family member making all the decisions. However, because microfinance reaches door-to-door of the rural poor women and youth, it encourages them to save and engage in economic activities (Gnawali, 2018). This will not only help women and youth have greater control over resources and their lives but also enable them earn income and participate actively in the public sphere as well as in decision making. Limbu (2014) stated that microfinance impacts on rural people and empower women and youth in many ways. It has provided opportunities for poor women to come out of their household confines and to organize themselves in groups as well as work in productive and social activities. Microfinance have a poverty reduction effect as well as it improves women and youth psychological and through social empowerment, thereby building their confidence and self-esteem to actively participate in household and community decision making processes (Salia et.al. I 2017).

\section{STUDY AREA}

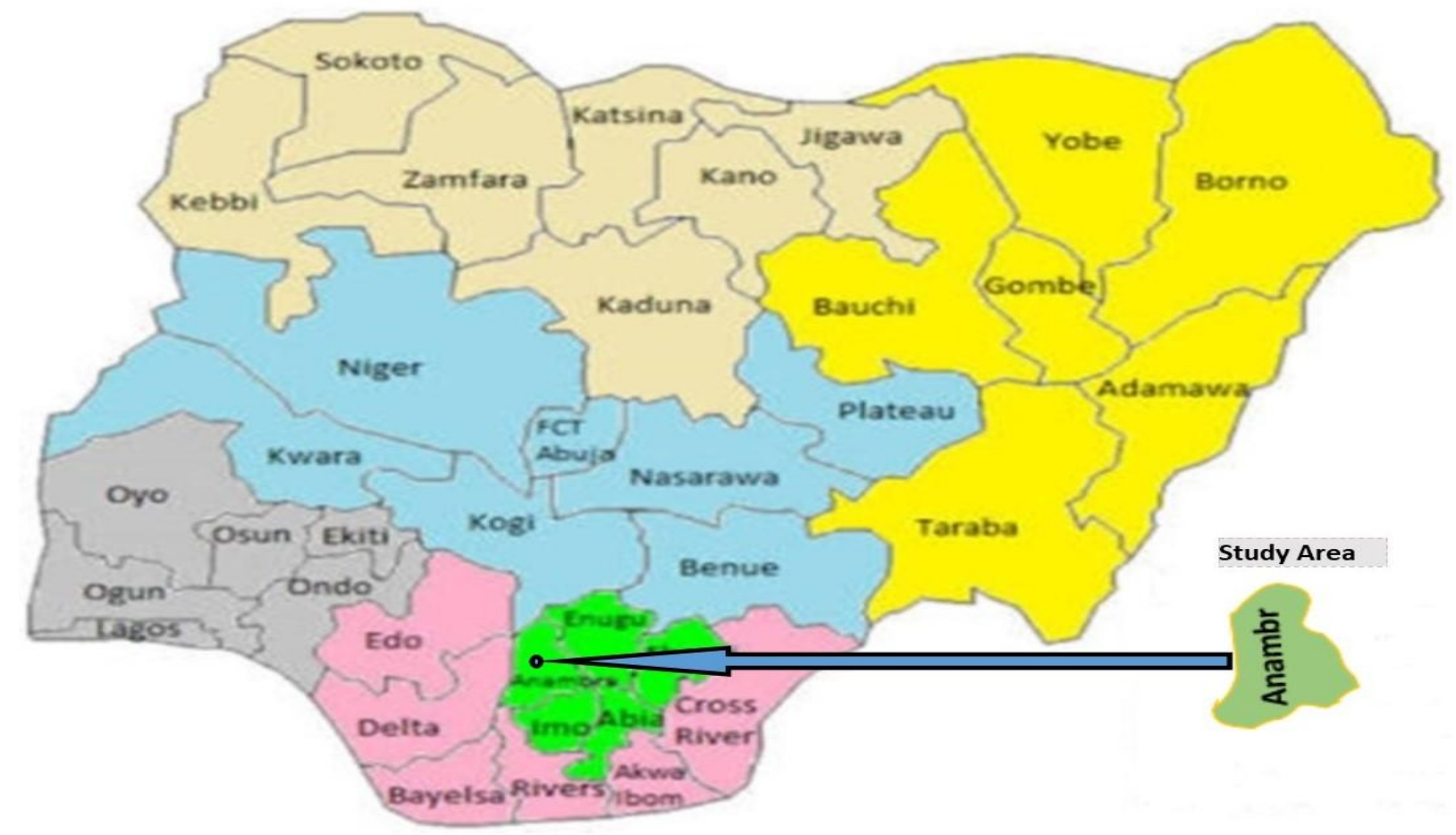

Figure 2: Map of Nigeria showing Anambra State 


\section{RESEARCH METHODOLOGY}

Information was gathered from primary sources. It involved the collection of data from those with requisite information, especially women and youth micro entrepreneurs who have benefitted from microfinance services in Anambra state.Face to Face interviews was used to primarily collect data from Eighty (80) respondents. The reason is to ensure high response and understand the respondents' perspectives while allowing discussions on their experiences.

\section{METHOD OF DATA ANALYSIS}

Information obtained to achieve the research objectives were analyzed using descriptive statistics as well as content analysis.

\section{RESULTS AND DISCUSSION}

Consideration was given to the socio-demographic characteristics of the respondents because of the critical role these play in understanding the social life of individuals, particularly those involved with the microfinance sector. These characteristics include age, gender, marital status educational (background, number of children etc). Age distribution of the respondents ranged from 20 years to 50 years and above.

The data in Table 1 showed the majority of the respondents interviewed were within the age bracket of 41-50 years with frequency of 31 representing $39 \%$ of the total respondents. The results also indicated the willingness of young people, especially women, to access microfinance services considering their age bracket.

Table 1: Age of Respondents

\begin{tabular}{|c|c|c|}
\hline Age (Year) & Frequency & Percentage (\%) \\
\hline Below 20 & 3 & $4 \%$ \\
\hline $20-30$ & 18 & $23 \%$ \\
\hline $31-40$ & 23 & $29 \%$ \\
\hline $41-50$ & 31 & $39 \%$ \\
\hline Above 50 & 5 & $6 \%$ \\
\hline Total & 80 & $100 \%$ \\
\hline \multicolumn{3}{|c|}{ Source: Researchers' field work } \\
\hline \multicolumn{3}{|c|}{ Age of Respondents } \\
\hline \multirow{5}{*}{$39 \%$} & & Below 20 \\
\hline & & $=20-30$ \\
\hline & & $=31-40$ \\
\hline & & - 41-50 \\
\hline & & Above 50 \\
\hline
\end{tabular}

Figure 3: Age of Respondent

On Marital Status, Table 2 below shows that majority (73\%) of the respondents are married while $11 \%$ are unmarried as against $3 \%$ and $14 \%$ for the divorced and widowed respectively.

Table 2: Marital Status of Respondents

\begin{tabular}{|l|l|l|}
\hline Status & Frequency & Percentage (\%) \\
\hline Married & 58 & $73 \%$ \\
Unmarried & 9 & $11 \%$ \\
Divorced & 2 & $3 \%$ \\
Widowed & 11 & $14 \%$ \\
\hline Total & $\mathbf{8 0}$ & $100 \%$ \\
\hline
\end{tabular}

Source: Researchers' field work 
Impact of Microfinance Services on the Empowerment of Women and Youth: Evidence from Rural Farmers in Anambra State, Nigeria

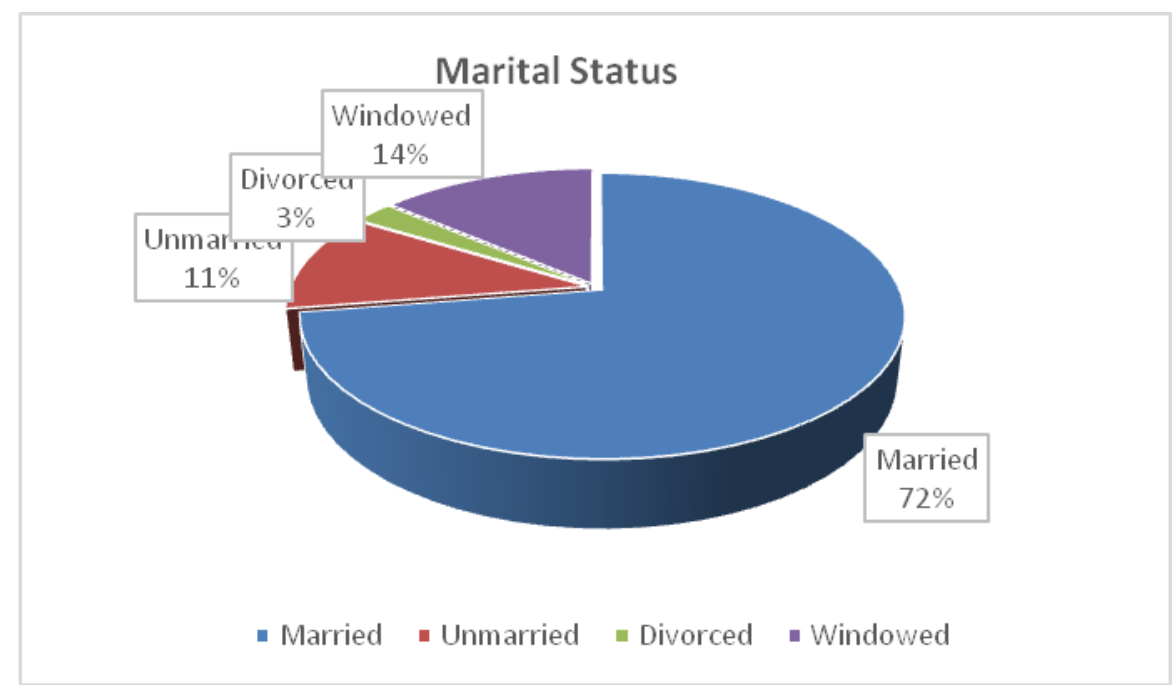

Figure 4: Marital Status

The number of children of the respondents is represented in Table 3 and Figure 5 below. The results revealed that $46 \%$ of the respondents had between 3 to 4 children, while $23 \%$ of them had between 1 and 2 children. The Table also indicated that $95 \%$ of the respondents were mothers and had at least a child. This demonstrates a huge social impact on the society.

Table 3: Number of children of Respondents

\begin{tabular}{|l|l|l|}
\hline No. of Children & Frequency & Percentage (\%) \\
\hline $1-2$ & 18 & $23 \%$ \\
$3-4$ & 37 & $46 \%$ \\
$5-6$ & 14 & $18 \%$ \\
7 \& above & 7 & $9 \%$ \\
No child & 4 & $5 \%$ \\
\hline Total & $\mathbf{8 0}$ & $100 \%$ \\
\hline
\end{tabular}

Source: Researchers' field work

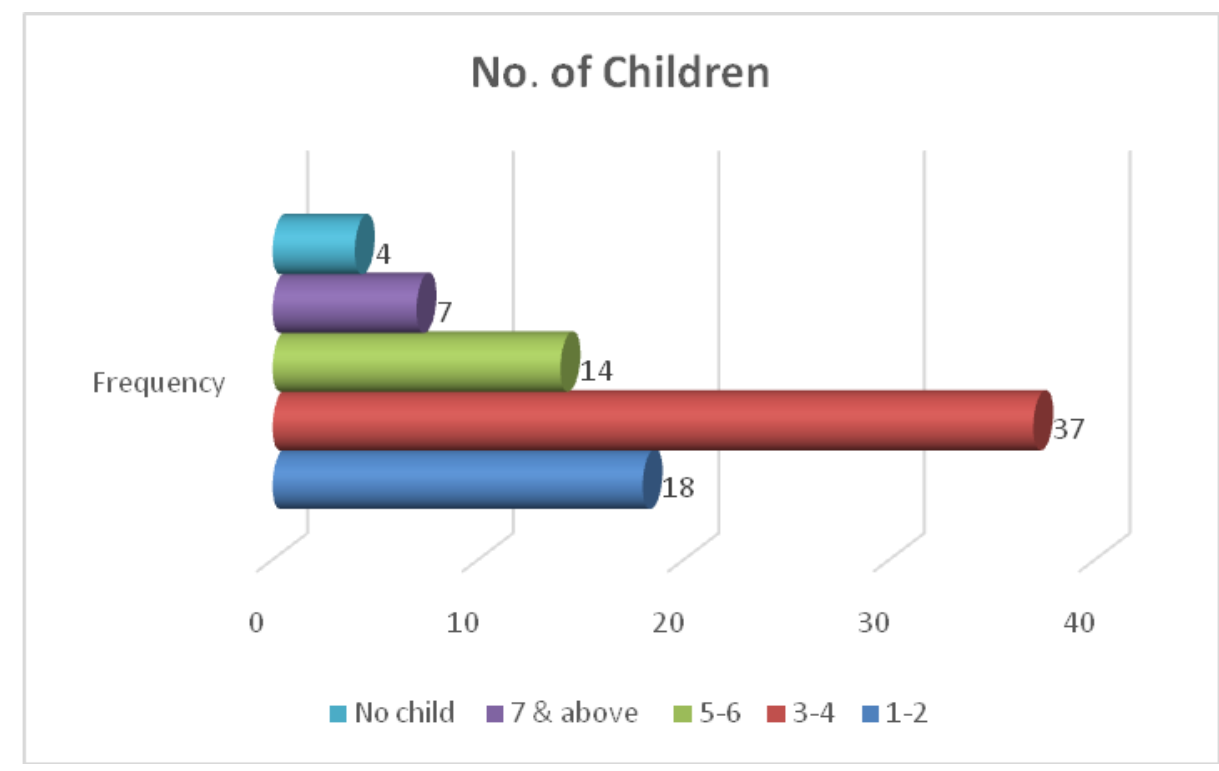

Figure 5: Number of Children

On Educational attainment, majority of the respondents had basic education with $59 \%$ of them having Secondary education. Those with Primary and Tertiary education accounted for $19 \%$ and $15 \%$ respectively, while only $3 \%$ of the respondents had no formal education. 


\begin{tabular}{|l|l|l|}
\hline Education & Frequency & Percentage (\%) \\
\hline No Formal Education & 2 & $3 \%$ \\
Primary Education & 15 & $19 \%$ \\
Secondary Education & 47 & $59 \%$ \\
Tertiary Education & 12 & $15 \%$ \\
Others & 4 & $5 \%$ \\
\hline Total & $\mathbf{8 0}$ & $100 \%$ \\
\hline
\end{tabular}

Source: Researchers' field work.

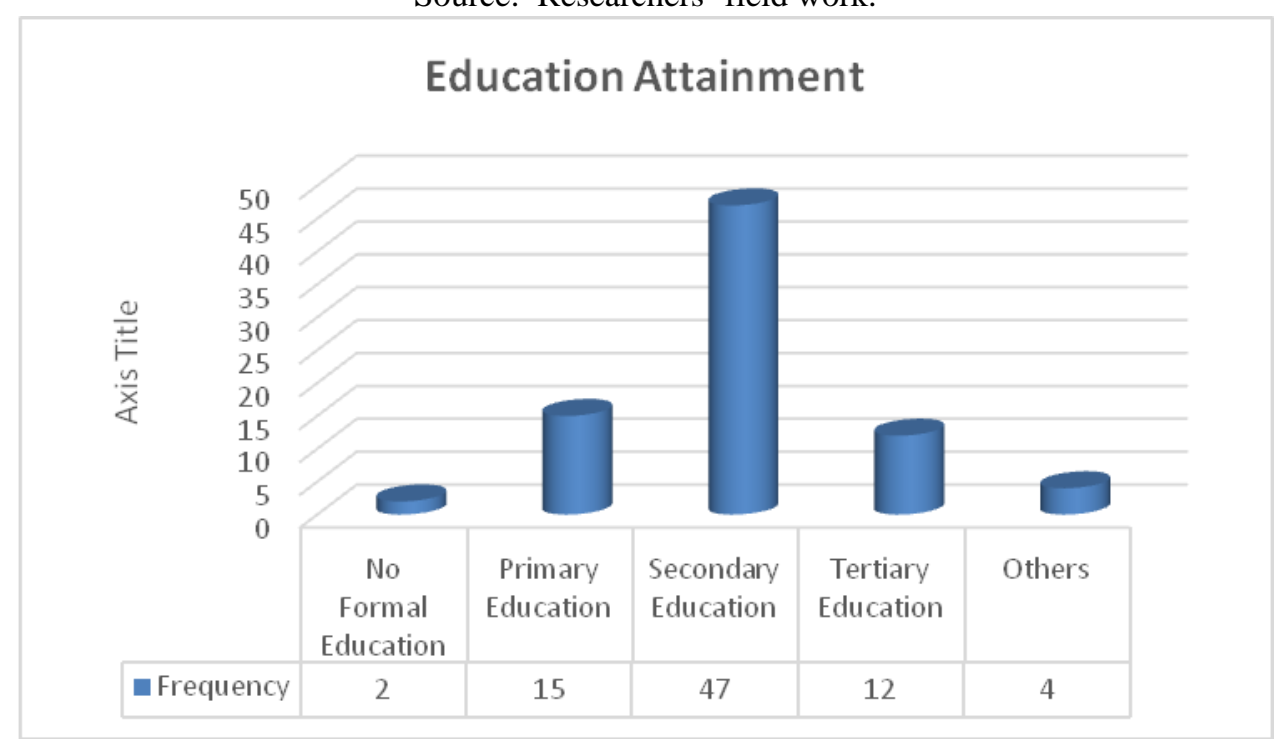

Figure 6: Education Attainment

In Nigeria, agriculture employs over $70 \%$ of the rural population with women playing a major role in the production, processing and marketing of food crops. However, only $64 \%$ of the respondents were found to be engaged in farm production activities, while $25 \%$ of them were into processing/marketing. A further $8 \%$ of the respondents were engaged in petty trading, while $4 \%$ were into other enterprises like Tailoring, Hairdressing etc.

Table 5: Types of Micro Enterprise

\begin{tabular}{|l|l|l|}
\hline Micro-Enterprise & Frequency & Percentage (\%) \\
\hline Farming & 51 & $64 \%$ \\
Processing/Marketing & 20 & $25 \%$ \\
& & $8 \%$ \\
Petty Trading & 6 & $4 \%$ \\
Others & 3 & $100 \%$ \\
\hline Total & $\mathbf{8 0}$ & \\
\hline
\end{tabular}

Source: Researchers' field work 
Impact of Microfinance Services on the Empowerment of Women and Youth: Evidence from Rural Farmers in Anambra State, Nigeria

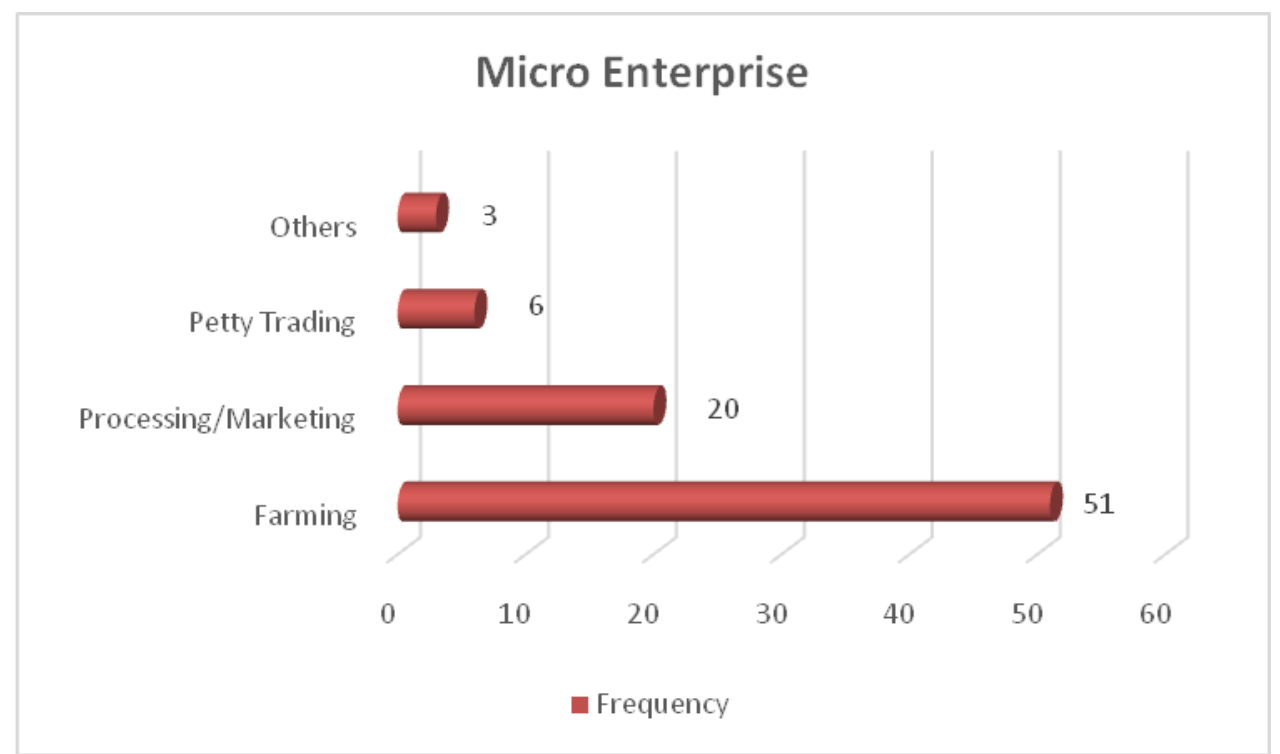

Figure 7: Micro Enterprise

In Table 6 below, 56 respondents representing $70 \%$ had 7 years and above experience in their chosen enterprise, while $24 \%$ of the respondents had between 5 and 6 years' experience. Interestingly, none of the respondents had experience below 3 years in their enterprise.

Table 6: Number of Years in Business

\begin{tabular}{|l|l|l|}
\hline Number of Years & Frequency & Percentage (\%) \\
\hline Under 1 & 0 & $0 \%$ \\
yr.1 - 2 & 0 & $0 \%$ \\
yr.3 - 4 & 5 & $6 \%$ \\
yr.5 - 6 & 19 & $24 \%$ \\
7 \& Above & 56 & $70 \%$ \\
\hline Total & $\mathbf{8 0}$ & $100 \%$ \\
\hline
\end{tabular}

Source: Researchers' field work.

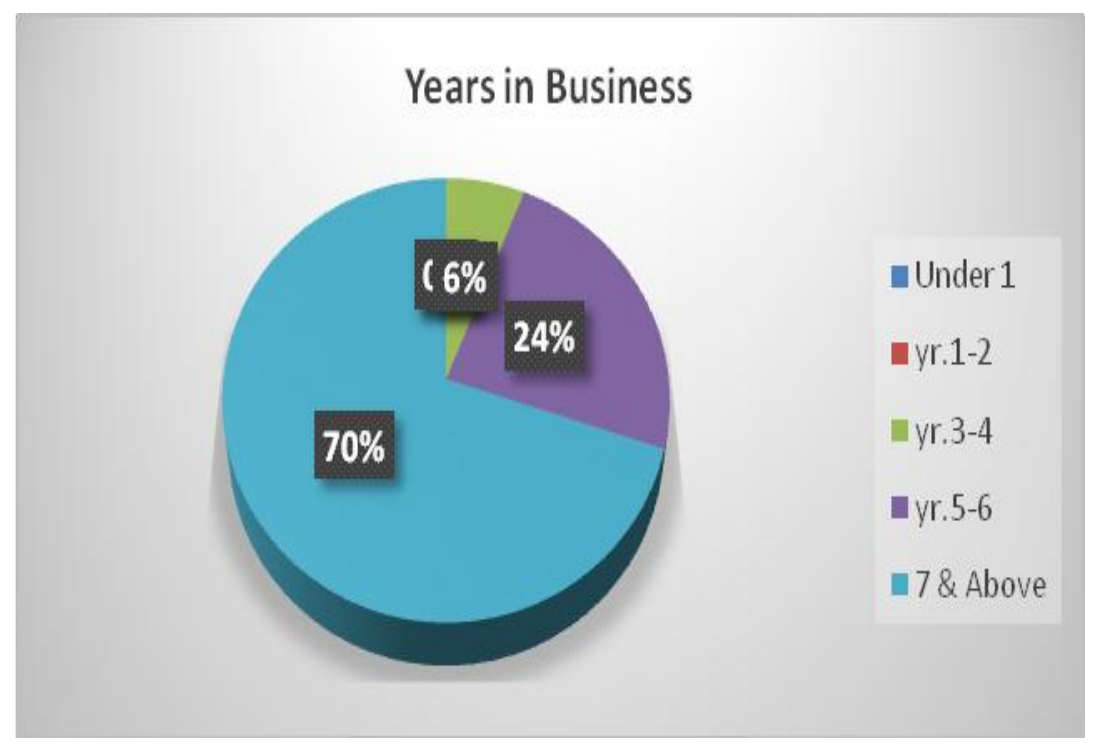

Figure 8: Years in Business 


\section{Content Analysis}

Table 7:Impact of Financial Services have on Women and Youth Smallholder Farmers/Entrepreneurs.

\begin{tabular}{|c|c|c|}
\hline $\begin{array}{l}\text { Characteristics of the Respondents } \\
\text { before Accessing Financial Services }\end{array}$ & $\begin{array}{l}\text { Characteristics of the Respondents } \\
\text { after Accessing Financial Services }\end{array}$ & $\begin{array}{c}\begin{array}{c}\text { Challenges of } \\
\text { Respondents }\end{array} \\
\text { Pese }\end{array}$ \\
\hline $\begin{array}{l}\text { - Lack access to credit and financial } \\
\text { Institutions }\end{array}$ & $\begin{array}{l}\text { - Access to Credit and Financial } \\
\text { Institutions }\end{array}$ & $\begin{array}{l}\text { - Inadequate amount of } \\
\text { funds available }\end{array}$ \\
\hline - Low Income & - Improved Income & - Untimely release of funds \\
\hline - Low Agricultural Output & $\begin{array}{l}\text { - Improved Agricultural Output and } \\
\text { Food Security. }\end{array}$ & $\begin{array}{c}\text { - Short period for loan } \\
\text { repayment }\end{array}$ \\
\hline - Poor Standard of Living & 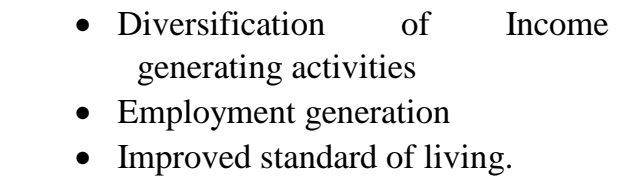 & $\begin{array}{l}\text { - Lack of storage facilities } \\
\text { and poor infrastructure } \\
\text { - Lack of easy access to land } \\
\text { and other farm inputs }\end{array}$ \\
\hline
\end{tabular}

The majority of the respondents( $92 \%)$ stated that access to financial services aided them to increase their production as well as diversify to other income generating activities. The respondents also acknowledged significant differences in the availability of food to their families when compared to the period they did not have access to financial services. Majority of the respondents (87\%)also stated that they were able to send their children to school as a result of the additional income generated, thereby noted the general improvement to their health and living standard. The study also revealed lack of access to land for agricultural purposes as a major challenge to the respondents because women and youth usually do not own land.Furthermore, majority of the respondents (79\%) stated that they have absolute control over their loans which enabled them to establish any enterprise of their choice. Also majority of them $(65 \%)$ have access to micro savings and credit.

\section{LIMITATIONS OF THE STUDY}

The researchers only used primary sources to generate the data which was time consuming, and as such they could not access a very large sample population.

\section{CONCLUSION}

The study highlights that age, education, marital status, family type are influential factors in relation to their impact on economic, social and political and health and education improvement of women and youth. In the study, the number of children significantly impacted positively among the beneficiaries of microfinance services. The study provided reasons for targeting women and youth by microfinance services as a means of empowering them. It was recognized that microfinance services brought about changes in the lives of women and youth, their household condition, family wellbeing and social status. The study corroborated the conclusions of Rahman et.al (2015) that increased incomesfor women and youth play a very critical role in enhancing their independence. However, societal discrimination still prevails, it was found and this in turn limited women and youth from fully exercising their potentials for the general wellbeing of their families. This research also supported the findings of Qazi (2013) that revealed that microfinance services improved the economic conditions, social status, standard of living, employment generation and overall wellbeing of the rural populace.

\section{REFERENCES}

[1] G. Addai, B.Women Empowerment through Microfinance: Empirical Evidence from Ghana Email address, Journal of Finance and Accounting, 2017, .5.

[2] Akhter, M.S and Islam, R.. Impact of Microfinance on Empowerment of Rural Women in Bangladesh: Evidences from some selected studies, Social Science Journal, 2016, (20) University of Rajshahi Bangladesh.

[3] Al-hassan, S. Is microcredit a viable strategy for Empowering Women, A Review of Selected NGO programmes in Africa, Centre for Continuing Education and Interdisciplinary Research, University of Development Studies Ghana, 2011, 8 (1)

[4] Alshebami, A.S and Khandare, D.M. The Role of Microfinance for Empowerment of poor women in Yemen, International Journal of social work 2015, 2(1)

[5] Appiah, R. The Impact of Microfinance on the Empowerment of Rural Women: A case study of Asuogyaman District in Eastern Region, Thesis submitted to Institute of Distance Learning, Kwame Nkrumah University of Science and Technology, 2011

[6] Asim, S. Evaluating the impact of micro credit on women empowerment in Pakistan Lahore School of Economics, Centre for Research in Economics and Business (CREB) 2009

[7] Awojobi, O.N. Empowering women through Micro-finance: Evidence from Nigeria Australian Journal of Business and Management Research, 2014, 4 (1)

[8] Berglund, K. E. The effect of microfinance on the empowerment of women and its societal consequences, minor field studies Reports, Uppsala University, 2007.

[9] Datta, S.and Sahu, T.N. An Empirical Study on the Impact of Microfinance on Women Empowerment: Evidence from West Bengal, Indian Journal of Commerce and Management Studies, 2017, 8, (3)

[10] Daza, R.L. A pathway towards empowerment in post-conflict Colombia: The case of female victims of conflict in the Department of Meta (Master Dissertation) Norwegian University of Life Sciences ,2017

[11] Doyle, K. Microfinance in the Wake of Conflict: Challenges and opportunities US Agency for International Development, Global Bureau, Economic Growth Section, 1998.

[12] Gnawali, A. Impact of Microfinance Institutions in Women Economic Empowerment: With reference to Butwal Sub-Municipality. 


\section{Impact of Microfinance Services on the Empowerment of Women and Youth: Evidence from Rural Farmers in Anambra State, Nigeria}

International Journal of Research in Humanities and Social Studies, 2018, 5, (5):10-17.

[13] Herath, H,M.W.A, Guneartne, L.H.P. andSanderatne, N.Impact of Microfinance on women's empowerment: a case study on two microfinance institutions in Sri Lanka, Sri Lanka Journal of Social Science, 2016, 38 (1)

[14] Hung, A, Yoong, J \& Brown, E. Empowering women though financial awareness and education (QECD Working papers on Finance, Insurance and Private Pensions 2012, 14 (1)

[15] Kabeer, N. Economic Pathways to Women Empowerment and Active Citizenship: What does the evidence from Bangladesh tell us, the journal of Development Studies 2017, 53, (3)

[16] Kafle, S.P. Microfinance and Women's Empowerment: A case study of VDRC-Nepal in Jamuniya, Nepal, The Arctic University of Norway, 2015.

[17] Limbu, D.S. Role of Microfinance in Poverty Reduction and Women Empowerment: A case study of Morang district. Thesis Tribhuvan University, Central Department of Economic, Kathmandu, 2014.

[18] Mayoux L, Gender and Rural Microfinance: Reaching and empowering women, Guide for Practitioners, Rome IFAD, 2009

[19] Mayoux, L.(2002) Microfinance and women's Empowerment Rethinking best practice, Development Bulletin no. 57 pp 76-81.

[20] Mecha, N.S. The Role of Microfinance on Youth Empowerment. An Examination of Theoretical literature, International Journal of Scientific and Research publication, 2017, 7, (2)

[21] Mondal, W.I. Poverty alleviation and microcredit in Sub-Saharan Africa International Business and Economics Research Journal 2011, $8,(1)$

[22] Mukhooli C. Impact of Microfinance Programmes on Women's Empowerment in East Africa, Thesis submitted to Development studies, Murdoch University, Australia 2015,

[23] Nagaraja, B.Empowerment of women in India; A critical analysis, journal of Humanities and social science, 2003, 9 (2): 45-52.

[24] Nguyen, A.P. Microfinance and Women's Empowerment: An Empirical Evidence in Vietnam, Honours Thesis and Capstones. 386, 2018

[25] Njoora, L andKyalo, T.Effect of Microfinance Credit on SMEs in Ngong of Kajiado County in Kenya', International Journal of Social Science and Entrepreneurship. 2014, 1 (10): 395-405.

[27] Omunjalu, B.S and Fondo, F. The Role of Microfinance in Economic Empowerment of the Youth: A case of Mombasa County, Journal of Business Management 2014, 16 (5)

[28] Ondoro, C.O andOmena, D. Effect of Microfinance Services on the Financial Empowerment of Youth in Migori County, Kenya, Business and Management Review Journal,2012, 2 (3)

[29] Qazi, S.W, Isran, M.Isran, S. and Syed, N.A. Women Empowerment through Microcredit: Step towards Alleviating Feminization of Poverty', Journal of Management and Social Sciences, 2013, 9, (2):.9 22

[30]

[31] Rehman, H, Moazzam, A, and Ansari, N.Role of Microfinance Institutions in Women Empowerment': A Case Study of Akhuwat, Pakistan Research Journal of South Asian Studies, 2015, 30 (1): $107-125$.

[32]

[33] Rahman, M.M, Khanam, R. and Nghiem, S.H. The effect of microfinance on women's empowerment. New evidence from Bangladesh, International Journal of Social Economics, 2017, 44. (12): $1745-1757$

[34] Reed, L.R. State of the microcredit summit campaign report, Washington D. C.2011

[35] Reyes, L.A.D andFattori, G. Microfinance as a means for Women Empowerment in the Colombian, Post Conflict Scenario: Transformation Development or a Tool for Better Managing Poverty, Peace Human Right Governance, 2019, 3.(1)

[36] Salia, S. Hussain, J. andTingbani, I. Is women empowerment a zero sum game? Unintended consequences of microfinance for women's empowerment in Ghana, Munich Personal Repec Archive, Paper no. 82895. 2017

[37] Selome, J. andTshuma, N.Microfinance and Women Empowerment in Zimbabwe: A case of Women Development Fund in Umguza district, International Letters of Social and Humanistic Science 2014, 35: 74-85.

[38] Shakya, K. Microfinance and Women Empowerment Thesis submitted to Arcada University of Applied Science Helsunki, Finland, 2016.

[39] Sinha, S. Microcredit impact, Targeting and sustainability, IDS Bulletin, 1998, 24, (9)
[40] Sujatha, G.and Malyadri, P.Impact of Microfinance on Women Empowerment: An Empirical Evidence from Andhra Pradesh', Journal of Entrepreneurship and organization Management 2015, 4 (2)

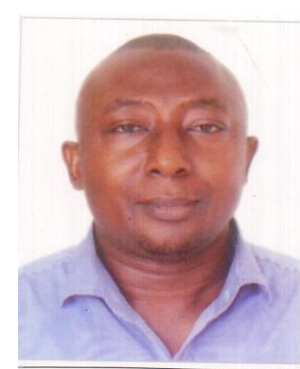

Longinus Chukwuma Ejiogu is a Principal Agricultural Officer with the Federal Ministry of Agriculture and Rural Development, Abuja Nigeria since 2006. He holds Master degree in Agribusiness from the University of Queensland Australia as well as Bachelor of Science of degree in Agricultural Economics and Extension from Abia State University, Uturu, Nigeria. His research interest focuses on Women and Youth Empowerment, Poverty Alleviation, Value Chain Management, Policy Development and Processes. He has also published in International Journals and worked with various International Donor Funded Projects in Nigeria such as International Fund for Agricultural Development (IFAD), Africa Development Bank (AfDB) etc.

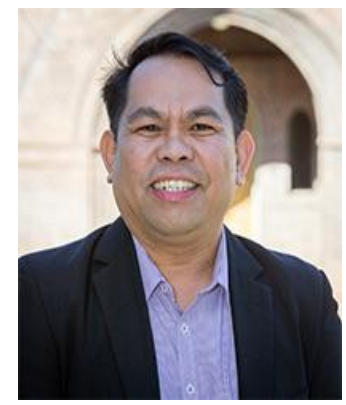

Renato Andrin Villano is a Professor of Economics and specializes in the area of Applied Econometrics, Agricultural Economics and Development Economics. His research activities focused on the areas of efficiency and productivity analysis, agricultural marketing, value chain analysis, risk analysis in production systems, poverty measurement and impact assessment. He has published in international and regional journals. He was a former Assistant Scientist and Visiting Research Fellow at the International Rice Research Institute at Los Baños, Philippines. He is also an Honorary Professor at Shandong Institute of Business and Technology, China. He was formerly an Associate Editor of the Australian Journal of Agricultural and Resource Economics and currently on the Editorial Board of the Journal of Agricultural and Applied Economics and the ASEAN Journal of Economics, Management and Accounting. He obtained his $\mathrm{PhD}$ at the University of New England, where he is also currently working as a Professor at the UNE Business School. 